\title{
DOI 10.26886/2414-634X.7(43)2020.7
}

UDC 327.5(045)

INFLUENCE OF POWER NARRATIVES ON THE FORMATION OF THE US FOREIGN POLICY IDENTITY IN THE $21^{\text {ST }}$ CENTURY

\section{lu. Tsyrfa, PhD of Political Science, Associate Professor}

https://orcid.org/0000-0002-7641-6964

e-mail: Julia_Tsyrfa@ukr.net

Institute International Relations of Taras Shevchenko Kyiv National University, Ukraine, Kyiv

Since today the constructivist study of international relations puts the social components of their formation in the foreground, the foreign policy identity of a state becomes primary thing in determining its national interests and its foreign policy course. Accordingly, the goal of this article is to determine the complex influence of power narratives on the formation of the US foreign policy identity in the $21^{\text {st }}$ century in the context of transformation of the domestic political matrix and redistribution of the influence between various political forces in this country. To achieve this goal, the author used the following research methods: the system analysis method, while determining the theoretical and methodological foundations for studying the phenomenon of foreign policy identity; the method of analogies and comparisons, while considering the power and political organization and institutionalization of the spatial structure of government in the United States; the method of comprehensive analysis, while establishing the main indicators of effectiveness of the influence of power narratives on the formation of the US foreign policy identity; the method of factor analysis, while substantiating the need to use individual approaches in building power narratives of the American politicians. As a result, the author determined that the US authorities form their narratives using an 
exclusive approach to the construction of collective identity of the society. However, such an algorithm is quite successful while forming stable foreign policy identity of the US.

Key words: foreign policy identity, USA, power, narrative, G. Bush, B. Obama, War on Terror.

кандидат политических наук, доцент,Ю. Цырфра, Влияние нарративов власти на фрормирование внешнеполитической идентичности США в XXI веке / Институт международных отношений Киевского национального университета имени Тараса Шевченко, Украина, г. Киев

Поскольку в наши дни конструктивистская парадигма исследования международных отношений ставит на первый план социальные составляющие их фрормирования, вопрос внешнеполитической идентичности государства является первичным в процессе определения его национальных интересов и направления курса внешней политики. Соответственно, целью данной статьи является определение комплексного воздействия нарративов власти на фрормирование внешнеполитической идентичности США в XXI веке ввиду трансорормации внутриполитической матрицы и перераспределения влияния в этой стране между различными политическими силами. Для реализации этой цели автор прибегал к таким методам исследования: системный анализ - при определении теоретико-методологических основ изучения френомена внешнеполитической идентичности; метод аналогий и сравнений - при рассмотрении властнополитической организации и институционализации пространственной структуры управления в США; комплексный анализ - при установлении основных показателей эфффективности влияния нарративов власти на формирование внешнеполитической 
идентичности США; фракторный анализ - при обосновании необходимости применения отдельных подходов при выстраивании нарративов власти американских политиков. Как результат, автором определено, что власти США фрормируют свои нарративы с учетом эксклюзивного подхода к прочессу выстраивания коллективной идентичности социума. Однако, такой алгоритм является довольно удачным во время конструирования стабильной внешнеполитической идентичности США.

Ключевые слова: внешнеполитическая идентичность, США, власть, нарратив, Дж. Буш, Б. Обама, война с терроризмом.

Введение. По завершению «холодной войны» в науке о международных отношениях произошло настоящее возрождение социального конструктивизма, ведь на фоне переформатирования мирового политического пространства представители данной научной школы выдвинули предположение о приоритетности социологических аспектов развития глобальных политических процессов. Следовательно, основную роль во время становления государств как ключевых акторов международных отношений играют не материальные, а нормативные структурные элементы, что, соответственно, повышает роль их внешнеполитических идентичностей, предоставляя им первостепенное значение в формировании интересов субъектов и взаимосвязанном конституировании агентов как ключевых элементов мировых сетей дву- и многосторонних связей. Поскольку немалое внимание конструктивистской парадигмы сосредоточено на роли нарративов власти в процессе формирования внешнеполитической идентичности государства, большой интерес сейчас вызывает их значение во время трансформационного периода внешней политики, связанного с 
войнами, конфликтами и изменениями глобальных приоритетов. Следовательно, исследования влияния нарративов власти на формирование внешнеполитической идентичности США как самого сильного актора мировой политической сцены в начале XXI века ныне имеют большое теоретическое и практическое значение.

В свое время тематике конструирования внешнеполитической идентичности Соединенных Штатов после террористических атак 11 сентября 2001 года уделяли немалое внимание такие исследователи как Р. Джевис [3], Р. Джексон [6], Дж. Джиллис [9], Р. Ньюманн [7], Д. Свит [5], М. Стаки [12], С. Хантингтон [10] и т. д. Однако эти ученые не осуществили комплексного анализа тенденций влияния на данный процесс нарративов власти с учетом изменений в распределении политических сил в пределах государства и, соответственно, их внутри- и внешнеполитических приоритетов.

Цель статьи. Поэтому, учитывая актуальность темы и ее точечные исследования в научной литературе, целью данной статьи является определение комплексного воздействия нарративов власти на формирование внешнеполитической идентичности США в XXI веке ввиду трансформации внутриполитической матрицы и перераспределения влияния в этой стране между различными политическими силами.

Изложение основного материала. Видение внешнеполитической идентичности США, сформированное представителями администрации Президента Дж. Буша-младшего в начале XXI века, содержало четкую конкретизацию образов врагов страны и, соответственно, влияло на конструирование внешней политики государства после террористических атак 11 сентября 2001 года и в течение Войны в Ираке, которая началась в 2003 году. Распространение риторики «страха, патриотизма, потребления и 
виктимизации» американского народа посредством массовой культуры и работы СМИ помогло Дж. Бушу убедить американцев в необходимости переоценки внешнеполитической идентичности государства и, следовательно, подготовить их к войне, ведь терроризм должен был восприниматься не как стратегия, а как «условие» [1, с. 290]. Высокопоставленные чиновники сгенерировали обновленный образ Соединенных Штатов: последние предстали в виде народа, который будет находиться под угрозой до тех пор, пока все враги этого государства не будут уничтожены. Такая внешняя угроза, по их мнению, исходила от террористических групп, лояльных к террористам стран и так называемых «государств-изгоев», которые на практике не могли бы выиграть войну против США, поэтому обратились к «вредоносным» стратегиям ведения внешней политики вроде применения оружия массового уничтожения или участия в «варварских» террористических атаках.

Первоначально американцы открыто назывались потенциальными жертвами будущих террористических атак, поскольку акции врагов были «бомбой замедленного действия» [2]. Осознание существования такого уязвимого образа американского народа заставляло отдельных индивидов обращаться к их коллективным идентичностям, которые в совокупности могли бы поддерживать идентичность социума, ведь последняя могла бы стабилизировать и укрепить единую внешнеполитическую идентичность США. Дж. Буш утверждал, что демократия и мир являются ключом к выстраиванию мощной государственной идентичности Соединенных Штатов и, соответственно, к реализации ими определенной внешней политики. По мнению Президента США, мир всегда будет оставаться ареной борьбы между «цивилизацией» и «терроризмом», или между «добром» и «злом». При таких условиях основной ролью американцев 
является защита свободы и демократии. Следовательно, существующие в мире диктаторские режимы рассматривались как «агрессивные», «жестокие», «демонические» и иррациональные: это легитимировало ведение военных действий администрацией Дж. Буша с целью отстранения от власти подобных правительств [3, с. 80-83].

В тексте так называемой «Доктрины Буша» - новой Стратегии национальной безопасности США 2002 года - подчеркивалась необходимость вступления страны в «выдающуюся» войну на принципах унилатерализма. Согласно документу, террористические атаки 11 сентября 2001 года состоялось по той причине, что США - это самая яркая «путеводная звезда» для свободы и возможностей [4]. Поэтому война, которую Соединенные Штаты начали против террористов, стала своего рода «цивилизационным противостоянием», ведь позже и лидер Ирака С. Хуссейн обвинялся не только в отсутствии демократии и уважения к правам человека в его стране, но и в открытой помощи и содействию Аль-Каиде.

Приписывая врагам США демонические характеристики, Дж. Буш автоматически причислял всех американцев к числу сознательных, честных граждан. C помощью его риторики выстраивался образ американского народа, абсолютно противоположный изображениям врага, что в результате не только облегчало, но и легитимировало борьбу с ним. Восприятие американцев в качестве идеальных или даже мифических граждан, производимое Дж. Бушем, активно поддерживалось различными СМИ. В начале войны в Ираке такая интерпелляция была довольно удачной, однако после ряда неудач в разведывательной сфере, фиксирования значительного количества потерь и, наконец, продолжения войны отношение жителей США к сложившейся внешнеполитической идентичности государства начало меняться. 
Соответственно, заняв пост Президента Соединенных Штатов в 2009 году, Б. Обама первоочередно сфокусировался на необходимости обеспечения демографической инклюзивности американцев, представляющих различные расы, культуры и религиозные течения, ведь такая риторика могла полномасштабно отобразить сорормированное им видение внешнеполитической идентичности государства. Б. Обама считал американцев тем народом, который может выбирать, просчитывать и реализовывать совместные действия по конструированию единой идентичности, ведь он, будучи несовершенным, находится в процессе перманентного идентичностного обогащения [5, с. 602]. Однако, несмотря на открытое оппозиционное отношение к Войне в Ираке в начале своей президентской каденции, уже в 2011 году Б. Обама не только увеличил количество войск в Ираке на 30000 человек, но и вскоре начал еще одно вооруженное противостояние на Ближнем Востоке, пытаясь преодолеть так называемое «Исламское государство».

По мнению Р.Джексона, Б. Обама был не способен выйти за рамки развернутой войны с терроризмом, ведь он - лишь ее «охранник», который применял имеющиеся нарративы идентичности и мифы вместо того, чтобы предложить собственные, обновленные подходы: как результат, он должен был придерживаться отдельных позиций своего предшественника, Дж. Буша-младшего, по данному вопросу внешней политики [6, с. 407-408]. По мнению Б. Обамы, Соединенные Штаты являются исключительными, ведь они всегда противостояли пыткам, способствовали установлению верховенства права и поддерживали людей разных религиозных принадлежностей во всем мире. По сути, его видение стало своего рода трансформированным убеждением А. Линкольна о том, что США «последняя, лучшая надежда для всего Земного шара» [6, с. 408]. 
Американский лидер обращался в своих речах к религии как к объединительному элементу, подчеркивая необходимость взаимодействия религии и политики, ведь умеренная религиозность намного лучше, чем секуляризованный либерализм. То есть, Б. Обама обращался скорее к вопросам единения общества и становления внешнеполитической идентичности США изнутри, таким образом замалчивая роль в этом процессе военных действий и глобального противостояния.

Еще одним орудием, к которому активно прибегали американские политики, пытаясь определить различия между гражданами США и их врагами, можно считать символизм. Привлечение символов позволяет создавать абстрактные понятия врага и государства, что, в результате, значительно облегчает алгоритм восприятия войны со стороны рядовых американцев. На протяжении всей истории развития Соединенных Штатов почти $75 \%$ президентов не включали в свои внешнеполитические дискурсы понятие «народ» [7, с. 834], чаще концентрируя внимание на абстрактных феноменах вроде войны или категориях вроде врага. Таким образом, США рассматривались в качестве символа свободы, а их враги - как символы тирании и регресса. Поэтому при формировании внешнеполитических нарративов именно использование символизма как средства для формирования их содержания всегда помогало чиновникам в процессе легитимации войны благодаря простой «примитивизации» последней.

Кроме того, американские чиновники часто применяли так называемую «селективную историю», ведь с помощью отбора нужных исторических событий они могли усилить содержательную сущность дефиниций их «Я», «Мы»-идентичности американцев и идентификационный процесс США в целом. Выполняя данную задачу, они и сейчас используют своего рода «прописные истины» 
идентичностного нарратива: «крупнейшие победы, героические поражения и показательные проявления индивидуального или коллективного мужества ... а также отдельные правители, солдаты, поэты, ученые и другие харизматические фригуры» - те элементы жизни общества США, которые граждане, как ожидается, должны помнить для конструирования единой идентичности социума и, следовательно, внешнеполитической идентичности государства [8, с. 150].

По этому поводу некоторые исследователи отмечают, что трагические ситуации в жизни государства иногда имеют большее влияние на процесс единения его населения, чем триумфальные события. Ведь отдельные сообщества уникальны не только в вопросах выбора тех фрактов, которые нужно помнить, но и в отборе ситуаций, которые их заставляют забыть [9, с. 50]. Следовательно, постоянное напоминание гражданам об отдельных печальных страницах истории их государства может убедить их в необходимости восприятия и дальнейшей поддержки политики правительства.

С точки зрения С. Хантингтона, религия всегда была и остается «центральным элементом» формирования коллективной идентичности американцев как граждан одного государства, которое было основано по религиозным причинам: соответственно, сейчас жители США намного более религиозны, чем народы других постиндустриальных стран [10, с. 20]. Поэтому естественно, что политические деятели всегда стремились провести параллель между государственной идентичностью США и протестантской этикой их населения. В XIX веке все президенты Соединенных Штатов обращались в своих политических речах к Богу, несмотря на то, что религия не занимала достаточно весомой позиции в их жизни (за исключением А.Линкольна, конечно). Однако даже А.Линкольн не дал своего 
согласия на внесение фрраз «Господь Вседержитель» и «Господь Иисус Христос» в текст Конституции США [11, с. 152].

Президент США В.Вильсон совмещал христианскую модель покаяния и понятие патриотизма, заявляя, что в рамках последнего отдельный человек также ставит интересы народа выше своих собственных. Следовательно, основной миссией Соединенных Штатов является интернационализация американского понимания свободы, что, в конце концов, должно способствовать и экономическому процветанию государств [12, с. 192]. Подобно ему, Д. Эйзенхауэр стремился, чтобы действия США за рубежом доказывали божественность их миссии, ведь моральный долг американцев работать в пользу других, что впоследствии было заложено в основу их роли активного лидера в XXI веке [12, с. 246].

Выводы. Соответственно, в начале XXI века американские лидеры пытались повлиять на процесс конструирования коллективной идентичности населения для поддержания единой внешнеполитической идентичности США, используя риторику, которая показала свою действенность в исторической ретроспективе. Ведь образ американцев мифологизировался всегда: в политических нарративах они возникали как свободный, независимый, могущественный народ, для которого высшей ценностью является уважение к правам человека. Соответственно, они должны освобождать другие нации от порабощения; бороться со злом; преодолевать тиранию; делать мир более цивилизованным; и, принимая на себя все риски, «нести свет» в глобальном измерении. Поэтому они пользуются уважением как солдаты и граждане, которым свойственны глубинные патриотические чувства, самоотверженность, мужество и героизм в противостоянии со злом. Хотя, описывая американцев как настоящих христиан, которые удерживают 
первенство в мире, лидеры США часто не указывали требований, которых должен придерживаться индивид, чтобы иметь возможность называться настоящим гражданином Соединенных Штатов. Следовательно, в их нарративах прослеживался довольно эксклюзивный подход к процессу формирования коллективной идентичности. Однако, по нашему мнению, он является довольно удачным во время выстраивания стабильной внешнеполитической идентичности США.

\section{תumepamypa:}

1. Altheide, D. (2004). Consuming Terrorism. Symbolic Interaction, 27(3), 287-308.

2. President Bush's 2002 State of the Union Address. (2002). The Washington Post, 29 January. <https://www.washingtonpost.com/wpsrv/onpolitics/transcripts/sou012902.htm> (2020, November, 18).

3. Jewis, R. (2005). American Foreign Policy in a New Era. London: Routledge.

4. The National Security Strategy of the United States of America, 2002. Official web-site of the U.S. Department of State. <https://www.state.gov/documents/organization/63562.pdf> (2020, November, 18).

5. Sweet, D., McCue-Enser, M. (2010). Constituting 'the People' as Rhetorical Interruption: Barack Obama and the Unfinished Hopes of an Imperfect People. Communication Studies, 61(5), 602-622.

6. Jackson, R. (2011). Culture, Identity and Hegemony: Continuity and (the Lack of) Change in US Counterterrorism: Policy from Bush to Obama. International Politics, 48(2/3), 390-411. 
7. Coe, K., Neumann, R. (2011). Finding Foreigners in American National Identity: Presidential Discourse, People, and the International Community. International Journal of Communication, 5, 819-840.

8. Maleševic, S. (2006). Identity as Ideology: Understanding Ethnicity and Nationalism. New York: Palgrave/Macmillan.

9. Gillis, J. R. (1996). Commemorations: The Politics of National Identity. Princeton, NJ: Princeton University Press.

10. Huntington, S. P. (2004). Who Are We?: The Challenges to American National Identity. New York: Simon \& Schuster.

11. Schlesinger, A. M. (1993). The Disuniting of America: Reflections on a Multicultural Society. New York: Norton.

12. Stuckey, M. E. (2004). Defining Americans: The Presidency and National Identity. Lawrence, Kansas: The University Press of Kansas.

\section{References:}

1. Altheide, D. (2004). Consuming Terrorism. Symbolic Interaction, vol. 27, no. 3, 287-308. [in English].

2. President Bush's 2002 State of the Union Address. (2002). The Washington Post, 29 January. <https://www.washingtonpost.com/wpsrv/onpolitics/transcripts/sou012902.htm> (2020, November, 18). [in English].

3. Jewis, R. (2005). American Foreign Policy in a New Era. London: Routledge. [in English].

4. The National Security Strategy of the United States of America, 2002. Official web-site of the U.S. Department of State. <https://www.state.gov/documents/organization/63562.pdf> (2020, November, 18). [in English].

5. Sweet, D., McCue-Enser, M. (2010). Constituting 'the People' as Rhetorical Interruption: Barack Obama and the Unfinished Hopes of an 
Imperfect People. Communication Studies, vol. 61, no. 5, 602-622. [in English].

6. Jackson, R. (2011). Culture, Identity and Hegemony: Continuity and (the Lack of) Change in US Counterterrorism: Policy from Bush to Obama. International Politics, vol. 48, no. 2/3, 390-411. [in English].

7. Coe, K., Neumann, R. (2011). Finding Foreigners in American National Identity: Presidential Discourse, People, and the International Community. International Journal of Communication, no. 5, 819-840. [in English].

8. Maleševic, S. (2006). Identity as Ideology: Understanding Ethnicity and Nationalism. New York: Palgrave/Macmillan. [in English].

9. Gillis, J. R. (1996). Commemorations: The Politics of National Identity. Princeton, NJ: Princeton University Press. [in English].

10. Huntington, S. P. (2004). Who Are We?: The Challenges to American National Identity. New York: Simon \& Schuster. [in English].

11. Schlesinger, A. M. (1993). The Disuniting of America: Reflections on a Multicultural Society. New York: Norton. [in English].

Stuckey, M. E. (2004). Defining Americans: The Presidency and National Identity. Lawrence, Kansas: The University Press of Kansas.

Citation: Iu. Tsyrfa (2020). INFLUENCE OF POWER NARRATIVES ON THE FORMATION OF THE US FOREIGN POLICY IDENTITY IN THE 21ST CENTURY. New York. TK Meganom LLC. Innovative Solutions in Modern Science. 8(44). doi: 10.26886/2414-634X.7(43)2020.7

Copyright: lu. Tsyrfa (․ 2020. This is an openaccess article distributed under the terms of the Creative Commons Attribution License (CC BY). The use, distribution or reproduction in other forums is permitted, provided the original author(s) or licensor are credited and that the original publication in this journal is cited, in accordance with accepted academic practice. No use, distribution or reproduction is permitted which does not comply with these terms. 